\title{
Insulin-Like Growth Factor 2 mRNA Binding Protein 2
}

National Cancer Institute

\section{Source}

National Cancer Institute. Insulin-Like Growth Factor 2 mRNA Binding Protein 2. NCI

Thesaurus. Code C147851.

Insulin-like growth factor 2 mRNA-binding protein 2 (599 aa, $66 \mathrm{kDa}$ ) is encoded by the human IGF2BP2 gene. This protein plays a role in the translation, localization and stability of mRNA. 